\title{
Regional on-line air pollution modelling system in highly complex terrain
}

\author{
P. Mlakar, M. Z. Božnar \& B. Grašič \\ MEIS doo., Slovenia
}

\begin{abstract}
In the paper, a national project with the title "Prognostic and diagnostic integrated regional air pollution modelling system" is described. It shows that such a project can significantly contribute to the proper understanding of the air pollution in smaller regions with a very complex topography. It also describes how foreseen scientific problems were solved and the necessary testing, improvements and validation were made. The development of a Lagrangian particle model-based air pollution modelling system that works in an on-line diagnostic mode and covers air pollution from several industrial and other sources in the region over a highly complex terrain, is described. To achieve online efficiency some new methods of obtaining high resolution short-range meteorological fields derived from mesoscale models were developed and the implementation of advanced Lagrangian models, acceleration techniques and novel approaches for whole system integration are presented. The project's test bed was established as a novel approach to the overall treatment of the scientific - applicative project goal.

Keywords: on-line regional air pollution modelling system, Lagrangian particle dispersion model, Zasavje region, test bed, complex terrain, non-hydrostatic numerical weather forecast model, nesting.
\end{abstract}

\section{Introduction}

In some areas of Slovenia, local inhabitants or environmental associations are strongly against the operation of some industrial plants due to the air pollution they cause. These problems are regulated by the European directive of Integrated Pollution Prevention and Control (IPPC) which requires among others that the industrial source's influence on the ambient air is modelled once to obtain the 
IPPC permit. The future European directives that are now in the preparatory phase also emphasize the use of air pollution models in an on-line mode for informing the local community, as the state-of-the-art science is enabling this already. In this paper, a national project with the title "Prognostic and diagnostic integrated regional air pollution modelling system" is described. It shows that such a project can significantly contribute to the proper understanding of the air pollution in smaller regions with a very complex topography.

\section{Zasavje region}

In Zasavje, air pollution is a very serious problem. Pollutant concentration limit values in the atmosphere are exceeded many times; currently the greatest problem is due to dust particles PM10. Particle PM10 (dust fraction that is regulated by the EU directive) air pollution is one of the most important air pollution problems in Slovenia and also in the EU. Several measurement sites show that the basic norms for daily and yearly PM10 concentrations are not being achieved. Based on this fact, the European commission reminded Slovenia in June 2008 that actions should be made to achieve the EU directives' requirements for a lower ambient air pollution due to the particles PM10 (especially the new Directive 2008/50/ES on ambient air quality and cleaner air for Europe). Unfortunately the measures taken were not sufficient and therefore in July 2010 the European Commission started suing Slovenia in the Court of the European Union regarding this matter.

An air pollution modelling system in the atmosphere provides some answers regarding the causes for pollution and pollution mechanisms; in particular, it gives the answer to the spatial and temporal distribution of pollution. Although measuring stations provide very accurate results, mainly in terms of the highly complex terrain, these data represent only a very small area in the immediate vicinity of the measuring station. Highly complex orography and consequently very complex micrometeorological conditions over the small area of the municipalities of Zasavje represent a considerable scientific challenge for modelling both the meteorological conditions and the spread of pollutants in the atmosphere. This project will contribute towards a new dimension of the general understanding of the problem of the air pollution. From a scientific point of view, one of the important objectives of this project is to demonstrate the correlation (in space and time) between the modelled concentrations and the measured concentrations at the locations of the numerous automatic measuring stations in Zasavje.

\section{Regional air pollution modelling system}

At the European level, the European Commission in cooperation with the European Environment Agency set up a forum FAIRMODE [1], responsible for guidance on good practice and the correct usage of modelling tools for any purpose regarding the regulatory use, that is the use with the aim of modelling the concentration of pollutants in the atmosphere for pollution control purposes. 
The regional air pollution modelling system was developed within this project and is fully consistent with all the requirements imposed by FAIRMODE. Among the most important requirements, there are requirements for a previously successful validation of the modelling system in a similarly complex area (size of domain, terrain complexity and most of all a similar complexity of meteorological conditions) [2, 3]. Furthermore, it requires that when using modelling systems in order to assess the impacts of industrial sources, that the cell size in the horizontal direction is at the most $250 \mathrm{~m}$.

The air pollution modelling system is a mathematical tool which illustrates the mechanism of spreading the pollutants into the atmosphere. The modelling system based on the input data regarding the meteorological conditions and pollutant emissions, calculates the consequences of these emissions as the concentration in the atmosphere in the area of emission sources are taken into consideration. Emission sources that have not (yet) been entered into the system, are not shown by the modelling system (emissions from other industries, traffic, local furnaces, biomass combustion and combustion of wastes in the countryside etc.).

The modelling system that allows these calculations for the shown area in Zasavje is composed of several models and uses different input data. General presentation of the model is illustrated on Figure 2. For the most accurate matching of the modelled concentrations with the measured concentrations, high-quality input data are of key importance, especially the qualitative measured meteorological data in the area discussed. For now, the prognosticated data on their own are not yet a sufficient basis for modelling the air pollution spreading over such a complex terrain as Zasavje. In order to achieve the matching results of the models with the actual measured concentrations in space and time it is also necessary to include the local meteorological data measured by appropriate meteorological models.

\subsection{Emission}

In order to obtain a quality modelling system it is necessary to describe the emission as much as possible. This is only possible with industrial sources which emit pollutants through stacks. Part of the emissions cannot be included in the industrial sources as they cannot control the emissions through the stacks. In 2010, we teamed up with four major industrial sources which release the emissions into the atmosphere of Zasavje: the thermal power plant Termoelektrarna Trbovlje, the cement factory Lafarge Cement, the glass product manufacturing company Steklarna Hrastnik and the building material company IGM. They have presented us with a detailed description of the physical features of the dischargers (height, diameter, flow rate etc.) and the amount of pollutants that can be emitted into the air. These data are from the environmental protection permit which must not be exceeded. 


\subsection{Measured meteorological data}

The test bed of the regional air pollution modelling system which was started in 2010 includes the integration of the meteorological data from the national network for monitoring air quality of the Slovenian Environment Agency (Agencija za okolje Repulike Slovenije) and from the environmental measuring system of Termoelektrarna Trbovlje. Measured environmental data from stations are presented in Table 1. Station locations are shown on the right hand side of Figure 1 .

Table 1: $\quad$ Measured environmental data at the automatic stations.

\begin{tabular}{|l|c|c|c|c|c|}
\hline Station name / & Kovk & Dobovec & Kum & Ravenska vas & Prapretno \\
Parameter name & $\mathrm{x}$ & $\mathrm{x}$ & $\mathrm{x}$ & $\mathrm{x}$ & $\mathrm{x}$ \\
\hline Air temperature & $\mathrm{x}$ & $\mathrm{x}$ & $\mathrm{x}$ & $\mathrm{x}$ & $\mathrm{x}$ \\
\hline Relative humidity & $\mathrm{x}$ & & $\mathrm{x}$ & & \\
\hline Global solar radiation & $\mathrm{x}$ & $\mathrm{x}$ & $\mathrm{x}$ & $\mathrm{x}$ & $\mathrm{x}$ \\
\hline Wind & $\mathrm{x}$ & $\mathrm{x}$ & $\mathrm{x}$ & $\mathrm{x}$ & \\
\hline Dust PM10 & $\mathrm{x}$ & & & & \\
\hline SO2 & $\mathrm{x}$ & & & & \\
\hline NO & $\mathrm{x}$ & & & & \\
\hline NO2 & $\mathrm{x}$ & & & & \\
\hline NOx & & & & \\
\hline $\mathrm{O} 3$ & & & & & \\
\hline
\end{tabular}

\begin{tabular}{|l|c|c|c|c|c|}
\hline $\begin{array}{l}\text { Station name / } \\
\text { Parameter name }\end{array}$ & Lakonca & Trbovlje & Zagorje & Hrastnik & Mrzlica \\
\hline Air temperature & $\mathrm{x}$ & $\mathrm{x}$ & $\mathrm{x}$ & $\mathrm{x}$ & $\mathrm{x}$ \\
\hline Relative humidity & $\mathrm{x}$ & $\mathrm{x}$ & $\mathrm{x}$ & $\mathrm{x}$ & $\mathrm{x}$ \\
\hline Global solar radiation & & $\mathrm{x}$ & $\mathrm{x}$ & $\mathrm{x}$ & \\
\hline Wind & $\mathrm{x}$ & $\mathrm{x}$ & $\mathrm{x}$ & $\mathrm{x}$ & $\mathrm{x}$ \\
\hline Dust PM10 & & $\mathrm{x}$ & $\mathrm{x}$ & & \\
\hline SO2 & & $\mathrm{x}$ & $\mathrm{x}$ & $\mathrm{x}$ & \\
\hline NO & & $\mathrm{x}$ & & & \\
\hline NO2 & & $\mathrm{x}$ & & & \\
\hline NOx & & $\mathrm{x}$ & & $\mathrm{x}$ & \\
\hline $\mathrm{O} 3$ & & $\mathrm{x}$ & $\mathrm{x}$ & & \\
\hline
\end{tabular}

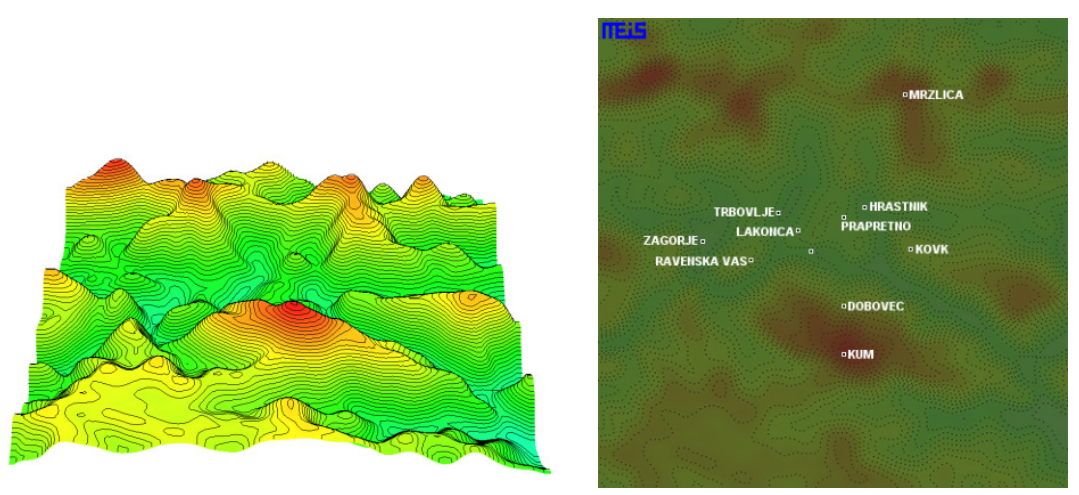

Figure 1: Zasavje region (left - 3D picture of orography, right - 2D picture with station locations). 

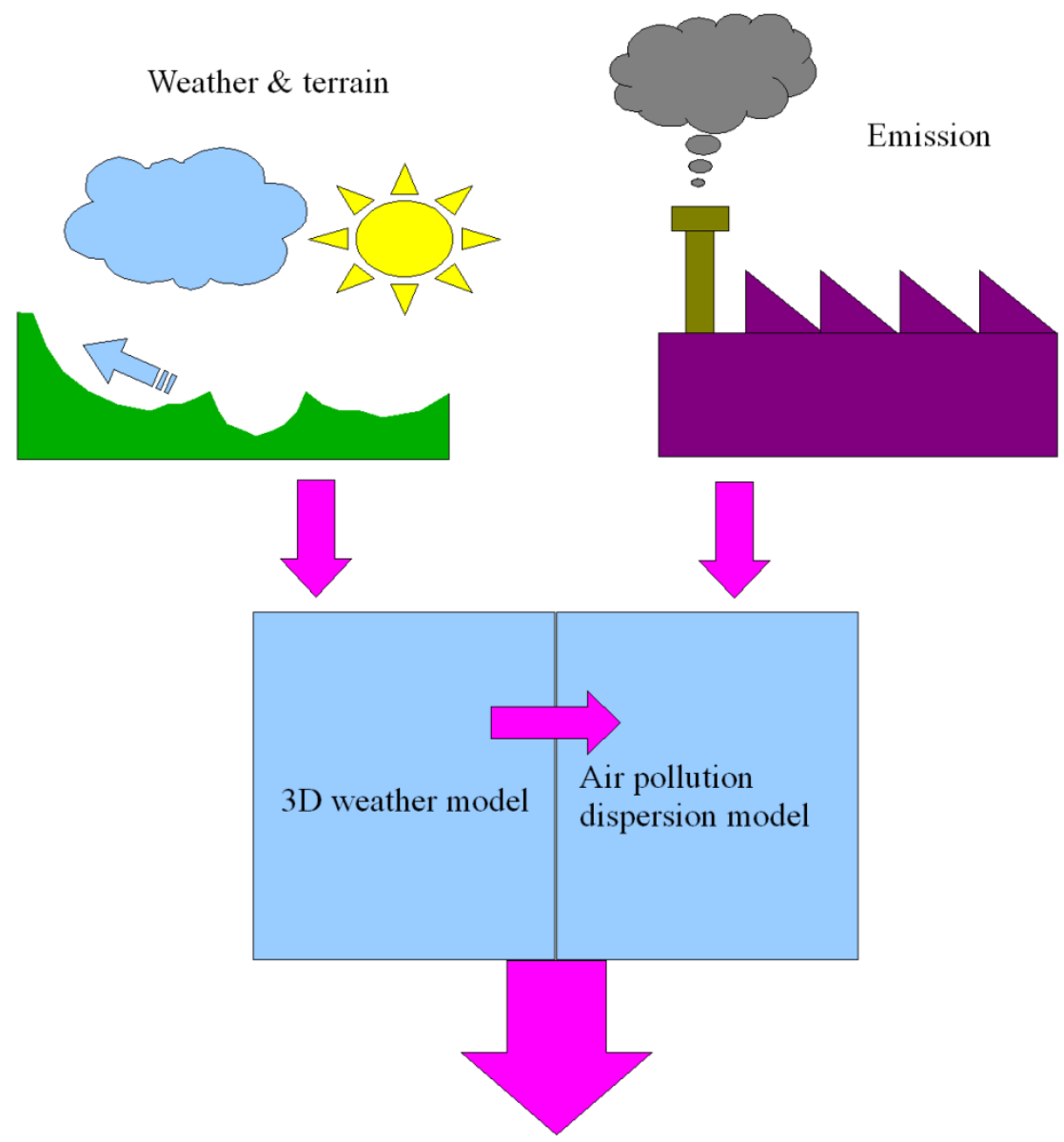

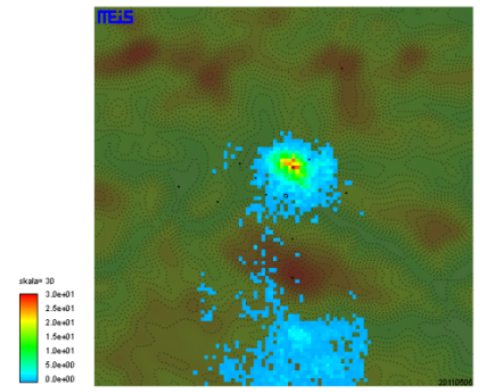

$2 \mathrm{D}$ ground level concentrations

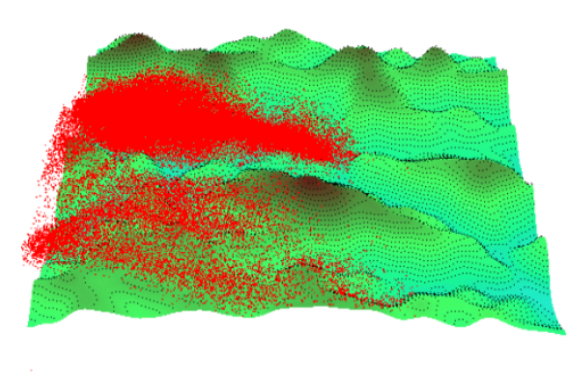

3D plume pictures

Figure 2: Regional air pollution modelling system. 


\subsection{Meteorological model}

In order to perform a diagnostic operation of our 3D air pollution modelling system we need prognostic data for the wind prognosis and temperature profile above the domain (as the only available measurements were performed on the ground), as measurements with the balloon are performed only once per day and those are in Ljubljana, and other advanced measurements (SODAR, RASS etc.) are not available for Zasavje. In the previous year, we chose the WRF Weather Research \& Forecast model [4], which consists of two Meso models ARW (Advanced Research WRF), maintained by NCAR [5], and the NMM (Nonhydrostatic Mesoscale Model), maintained by NOAA/NCEP [6]. The model frame (data acquisition, data processing) is common; the difference is only in the dynamic core. Both models were installed in different resolutions and with different numbers of nesting on a four core computer (Dual Core Quattro) with a 64 bit system Open SUSE. Boundary and initial data are provided by a global meteorological model GFS (NCEP centre from America). For our project, the module ARW was chosen, which was intended for research and the module NMM was intended for more routine weather prediction - however, we were interested in more specific meteorological features.

The configuration of the ARW model which has been running daily from February 2010 is as follows:

- two domains;

- duration of forecasting: 2 days and 3 hours;

- larger domain (Central Europe): $101 \times 101$ pixels in a resolution of $12 \mathrm{~km}$ per hour;

- smaller domain (Slovenia with surroundings): $76 \times 76$ pixels in a resolution of $4 \mathrm{~km}$ per $30 \mathrm{~min}$;

- the model starts running at 5:00 UTC;

- the simulation runs from 3 to 4 hours.

An example of cloudiness prediction with the nesting method on two areas of different sizes is shown in Figure 3 with an illustrative presentation of the size of each domain.

\subsection{Air pollution dispersion model}

At first, in order to register the meteorological conditions for every 30 minutes in a continuous mode, meteorological data from the automatic measuring stations in this area are used. As it is also essential to describe the vertical profile of the wind, temperature and relative air humidity, an approximation using a profile calculated by a prognostic meteorological model is used. Measurements with the SODAR would be more appropriate, unfortunately they are not available at the moment. All the data are processed by a meteorological pre-processor SurfPro and a three dimensional mass consistent wind model Swift [7-9] (both products by the company Arianet Srl). 


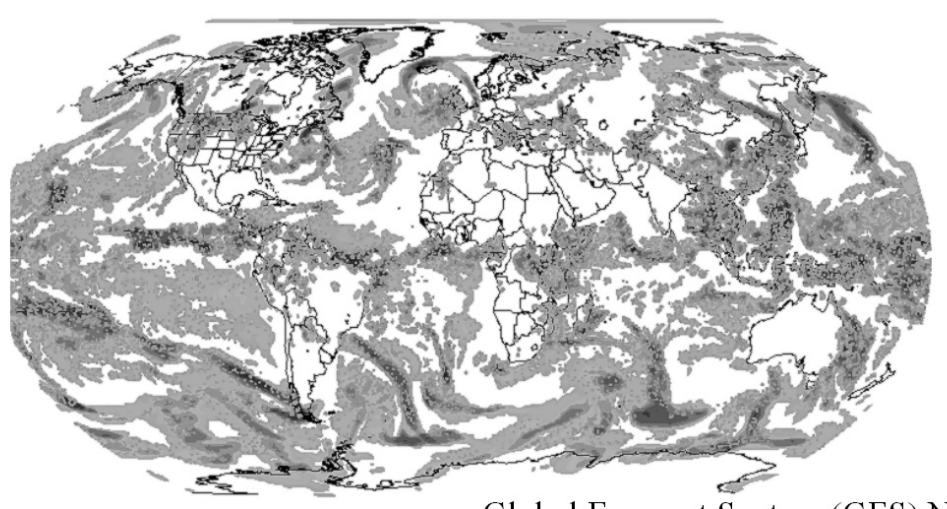

Global Forecast System (GFS) NCEP

$0.5^{\circ}$ longitude $x 0.5^{\circ}$ latitude every 3 hours

Oblaki [\%]

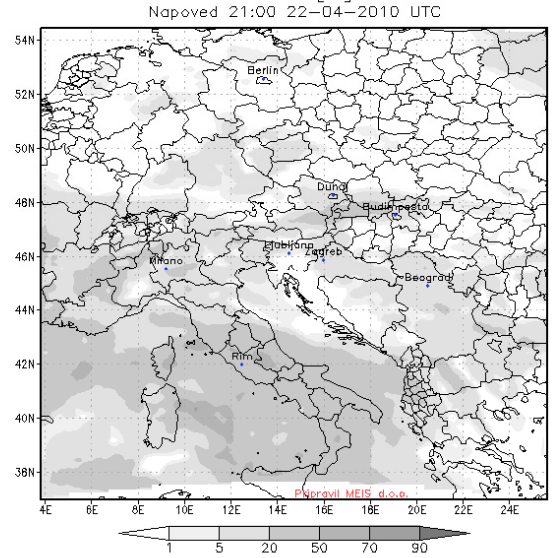

Central Europe resolution:

101 cells $\times 101$ cells of size $12 \mathrm{~km} \times 12 \mathrm{~km}$ every one hour

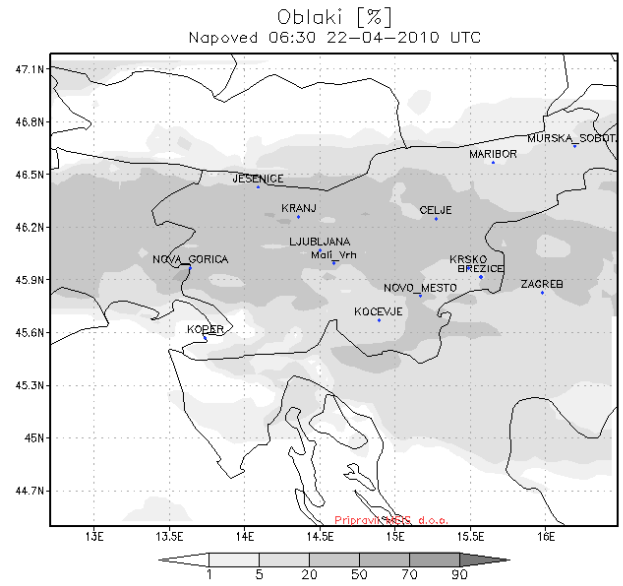

Slovenia resolution:

76 cells $x 76$ cells of size $4 \mathrm{~km} \times 4 \mathrm{~km}$ every half an hour

Figure 3: Example of forecast with the nesting. 
The modelling system also implements the data on the terrain altitude and land use, both in the above mentioned resolution.

Then, the movement of pollutants from their sources towards the hills and valleys is entered in this three-dimensional meteorological area, resulting in the calculated pollutant concentrations as shown in the Figures. For this part, a numerical Lagrangian particle model Spray [9] by the company Arianet Srl is used.

The above-mentioned approach in the current state of science in this area with complex terrain provides the best results. This is evidenced by the articles published in the scientific journals $[2,3]$.

The examples of the model results are shown in the lower part of Figure 2, on the left hand side is shown one of the modelled ground concentrations and on the right hand side, there is shown a $3 \mathrm{D}$ picture of the release of one of the sources.

\section{KOOREG - public internet portal}

All the results from the developed air pollution modelling system for Zasavje are given in real time and are available on-line in the portal site named KOOREG Air pollution control in the region. The portal site shows a concentration of pollutants $\mathrm{SO}_{2}, \mathrm{NO}_{2}$ and $\mathrm{PM}_{10}$ due to the operation of different sources of emissions into the atmosphere of Zasavje (http://www.kvalitetazraka.si).

During the first phase of the project, the portal site already shows the concentration of pollutants in the air in real time for each 30 minutes, for the past 2 days. The project specifically authorized the use of their nominal (normal maximum operating) emission values: The thermal power plant Termoelektrarna Trbovlje, the cement plant Lafarge Cement, the glass product manufacturing company Steklarna Hrastnik and the building material company IGM Zagorje. For now, only concentrations in the atmosphere which are the result of emissions from these sources are shown. In the modelling system these values are used as if these facilities are operating 24hours every day of the year, therefore the users of the portal site are asked to check the (non-) operation with the individual participant. In the future, we plan to use the simultaneous and automatic use of the emission values (where this is of interest).

Besides the concentration, the portal site also offers a current weather forecast for 48 hours in the future. There are forecasts for precipitation, cloudiness, wind, visibility, air pressure and temperature.

The portal is also equipped with a non-technical description of the modelling system and the portal site which is intended for the general public. The description is made in order to offer a concise and as simple and non-technical form as possible so that the end users would be able to become acquainted with the content of the portal site.

Figure 4 shows the home page. In the upper menu bar, general descriptions of the portal site, the modelling system and contact information are given. 


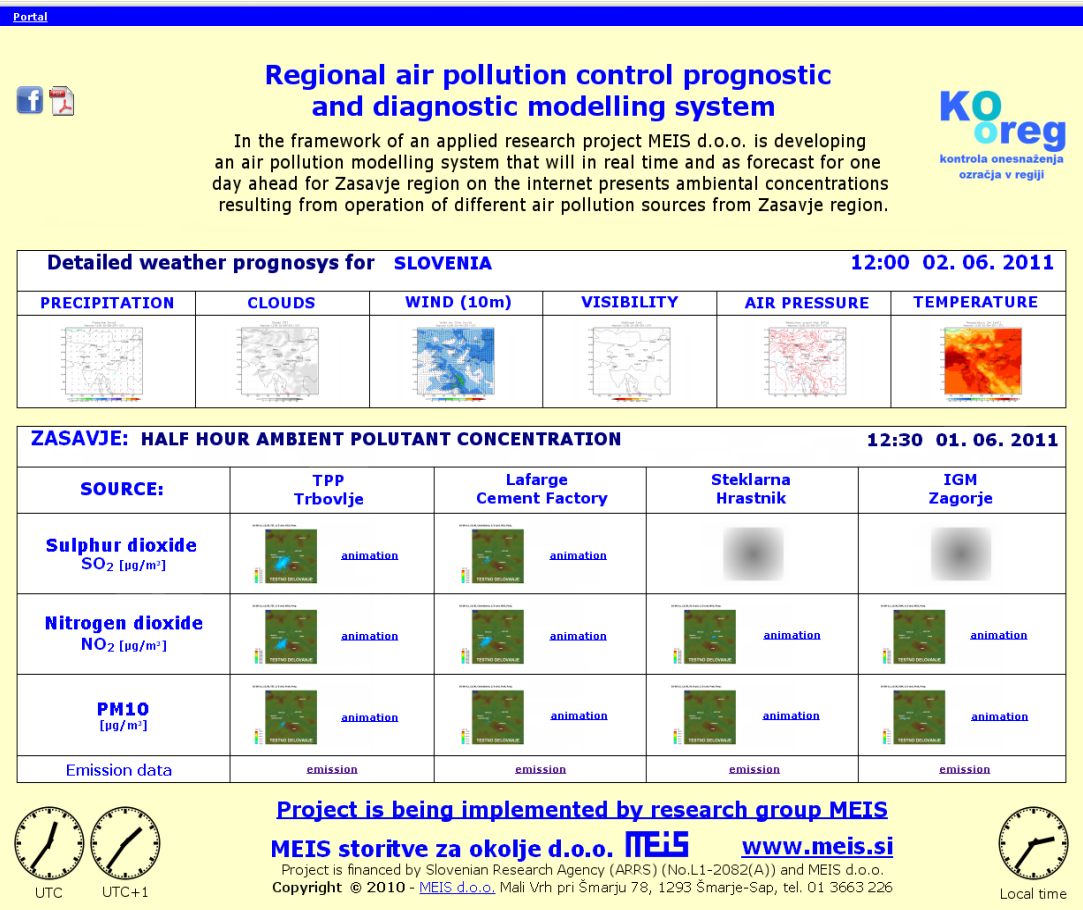

Figure 4: $\quad$ Public portal KOOREG (http://www.kvalitetazraka.si).

This is followed by the first group of results of the modelling system, consisting of a weather forecast. By clicking on one of the group pictures (e.g. temperature) another window opens, providing a detailed review of the predictions for 48 hours with an animation effect, as shown on the left hand side of Figure 5.

The second group of results of the modelling system is the average pollutant concentrations for every 30 minutes for the past 24 hours. By clicking on each picture another window opens with a detailed review of the last available concentrations. This is shown in Figure 6. In addition to the last concentration, there is also the criteria description for each pollutant and a legend which allows the user to determine the area with critical situations in a clear and simple way. By clicking on the animation capture another window opens which provide a detailed review of the predictions for the past 24 hours with an animation effect, as shown on the right hand side of Figure 5. 
56 Air Pollution XIX

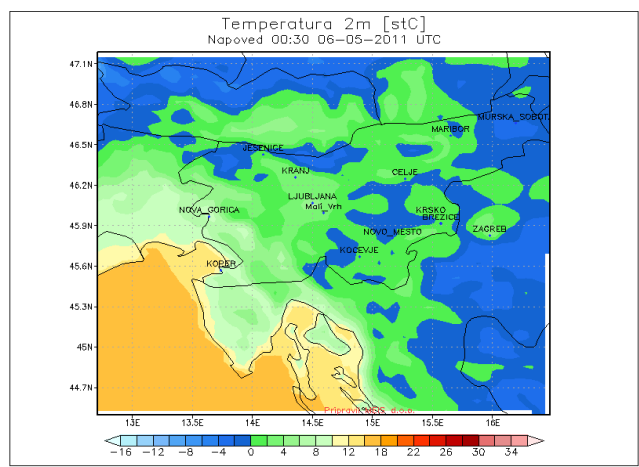

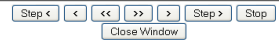

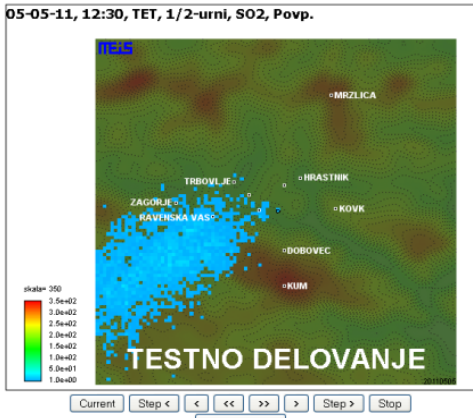

Close Window

Figure 5: Animation of results (left - temperature forecast for 48 hours in the future, right - air pollution $1 / 2$-hour concentrations for the last 24 hours) (TEST OPERATION).

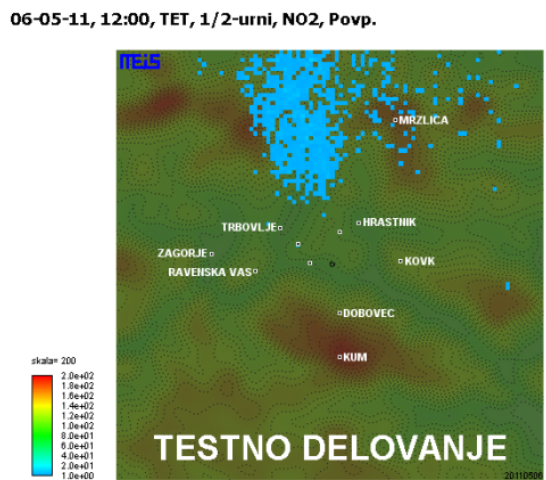

Figure 6: Example of $1 / 2$-hour air pollution concentration of $\mathrm{NO}_{2}$ from TPP Trbovlje. 


\section{Conclusions}

The regional air pollution modelling system gives a completely new way of monitoring the air pollution with the main purpose of providing a better living environment in Zasavje. The air pollution modelling system in the atmosphere provides several answers regarding the causes and pollution mechanisms, in particular the answer regarding the spatial and temporal distribution of the pollution. It is important that the modelling system used a set of models which had demonstrated in previous validations $[2,3]$ a well grounded matching of the modelled and the measured concentrations in space and time on this and a similarly complex terrain in Slovenia. The modelling system is intended for both the residents and the polluters. The portal site KOOREG with the modelling results is supposed to help people in order to think about pollution in a more comprehensive manner. They will also be able to find out in the portal site which of the polluters is responsible for the pollution. As one of these four polluters will not always be responsible for the pollution, eventually the system will try to also include smaller sources of air pollution which do not fall under the IPPC Regulation yet are strongly polluting the atmosphere in their immediate vicinity due to their unfavourable location. In the near future, the portal site will also be updated with the pollution prognosis for one day in advance. The pollution forecast will also be of help to the polluters who will be able to reduce the emissions for the approaching day and thereby help to mitigate the concentration of pollutants in the atmosphere.

\section{Acknowledgements}

The authors gratefully acknowledge the financing of the project by the Slovenian Research Agency, Project No. L1-2082. The authors would like to acknowledge all the four companies mentioned in this article (Termoelektrarna Trbovlje, Lafarge Cement, Steklarna Hrastnik and IGM Zagorje) for their voluntary participation in this project and their permission to use their nominal operating emission values.

\section{References}

[1] FAIRMODE., Guidance on the use of models for the European Air Quality Directive, working document of the Forum for Air Quality Modelling in Europe FAIRMODE ETC/ACC report Version 6.2, Editor: Bruce Denby, In: FAIRMODE. Available from: http://fairmode.ew.eea.europa.eu/ fol429189/forums-guidance/model_guidance_document_v6_2.pdf, 08.03.2011, 2010

[2] Grašič B., Božnar M. Z., Mlakar P., Re-evaluation of the Lagrangian particle modelling system on an experimental campaign in complex terrain, Il Nuovo Cimento C, Vol. 30, No. 6, pp. 557-575, 2007

[3] Božnar M., Mlakar P., Grašič B., Air pollution dispersion modelling around Thermal power plant Trbovlje in complex terrain: model verification and 
regulatory planning. V: Borrego, C. (ed.), Miranda, A. I. (ed.). Air pollution modeling and its application XIX : [proceedings of the 29th NATO/OCCMS International Technical Meeting on Air Pollution Modelling and its Application, Aveiro, Portugal, 24-28 September 2007], (NATO science for peace and security series, Series C, Environmental security). Dordrecht: Springer, cop. 2008, pp. 695-696, 2010

[4] WRF, The Weather Research \& Forecasting Model, Available from: http://www.wrf-model.org/, 10.05.2011

[5] The National Center for Atmospheric Research (NCAR), NCAR ARW WRF Forecast, Available from: http://www.wrf-model.org/plots/realtime main.php, 10.05.2011

[6] National Oceanic and Atmospheric Administration (NOAA)/National Centres for Environmental Prediction (NCEP), NMM Model Analyses and Forecasts, Available from: http://www.nco.ncep.noaa.gov/pmb/nwprod/ analysis/namer/hiresw/12/model_l.shtml

[7] Brusasca G., Tinarelli G., Anfossi D., Particle model simulation of diffusion in low windspeed stable conditions", Atmospheric Environment Vol. 26, pp. 707-723, 1992

[8] Anfossi D., Ferrero E., Brusasca G., Marzorati A., Tinarelli G., A simple way of computing buoyant plume rise in Lagrangian stochastic dispersion models, Atmospheric Environment Vol. 27A, pp. 1443-1451, 1993

[9] Tinarelli G., Anfossi D., Bider M., Ferrero E., Trini Casteli S., A new high performance version of Lagrangian particle dispersion model SPRAY, some case studies., Air pollution modelling and its Applications XIII, S. E. Gryning and E. Batchvarova eds., Kluwer Academic / Plenum Press, New York, pp. 499-507, 2000 